\title{
Characterization and vectorization of siRNA targeting RET/PTC1 in human papillary thyroid carcinoma cells
}

\author{
L. Massade \\ Universite Paris-Sud, UMR 8203, Orsay, \\ F-91405, CNRS, Orsay, F-91405, Institut Gustave Roussy, Villejuif 94805 \\ UMR 8203 CNRS, Institut Gustave Roussy \\ F-94805 Villejuif Cedex, France \\ liliane.massade@igr.fr
}

\begin{abstract}
RET/PTC1 fusion oncogene is the most common genetic alteration identified to date in thyroid papillary carcinomas (PTC) and represents a good target for small interfering RNA (siRNA). Our aim was: i) to target the RET/PTC1 oncogene by siRNAs, ii) to assess the knockdown effects on cell growth and cell cycle regulation and iii) to vectorize it in order to protect it from degradation. Methods. Human cell lines expressing RET/PTC1 were transfected by siRNA RET/PTC1, inhibition of the oncogene expression was assessed by $q R T-P C R$ and by Western blot. Conjugation of siRNA RET/PTC1 to squalene was performed by coupling it to squalene. In vivo studies are performed in nude mice. Conclusion. In this short com-munication, we report the main published results obtained during last years.
\end{abstract}

Keywords: RET/PTC1, siRNA, thyroid papillary carcinomas.

Introduction. Cancers due to chromosomal translocations are considered to represent around $20 \%$ of all cancers [1]. Genomic rearrangements leading to intragenic fusion are mainly found in some types of haematopoietic malignancies and sarcomas. They have recently been described also in carcinomas $[2,3]$. The mechanism of formation of most of these translocations is still unclear, except for RET oncogene in papillary thyroid carcinomas (PTC) where ionizing radiation is described as an important factor [4]. Thus, thousands of people developed thyroid cancers after the Chernobyl catastrophe $[5,6]$. The RET/PTC oncogene was isolated almost twenty years ago $[7,8]$. RET/PTC is an early event in the process of thyroid carcinogenesis and plays a critical role in the generation of papillary carcinoma [9]. The RET protooncogene codes for a cell membrane receptor tyro sine kinase and has a role in the regulation of cell growth, survival, differentiation and migration [10].

(C) Institute of Molecular Biology and Genetics, NAS of Ukraine, 2011
Rearrangement involving the chromosome 10 between RET and a ubiquitous gene leads to the abnormal expression of a chimeric constitutively activated RET protein in follicular cells [11]. To date, 12 different fusion pattern genes have been reported to form at least 17 different RET hybrid oncogenes. The spatial proximity of Ret gene with $\mathrm{H} 4$ during thyrocyte interphase can explain the RET/PTC1 formation [12]. This fusion oncogene is essentially restricted to the papillary histotype (60-70\%) [13] and to the Hurthle thyroid tumours (58 \%) [14] and its incidence increases after radiation exposure.

Moreover, the RET/PTC1 fusion oncogene is present only in the tumour cells and not in the surrounding normal cells, this constitutes an area of important research on emerging therapies such as using small interfering RNA (siRNA) to target. Therefore, we targeted the RET/PTC1 oncogene by siRNAs and assessed the knockdown effects on cell growth and cell cycle regulation, then we vectorized it because the biological 
efficacy of the siRNAs is hampered by their short plasmatic half-life due to poor stability in biological fluids and by their low intracellular penetration due to their highly hydrophilic character $[15,16]$.

Material and methods. The human TPC-1 cell line that harbours the RET/PTC1 rearrangement was used. A siRNA targeted to H4/RET termed siRNA RET/PTC1 was designed to knockdown RET/PTC1 in the TPC-1 cells. It was transiently transfected in TPC-1 cells using Lipofectamine 2000 transfection reagent. Then, total RNA was extracted and first-strand cDNA was generated with M-MLV (Reverse Transcription), real time PCR Q-RT-PCR was used to assess the knockdown efficiency.

Western blot was performed using Ret antibody and $\beta$-actin was used as loading control. The siRNA RET/ PTC1 effects on cell cycle growth (MTT tests), cell cycle (flow cytometry) and apoptosis (TUNEL method) were studied (Fig. 1).

$A$

$B$
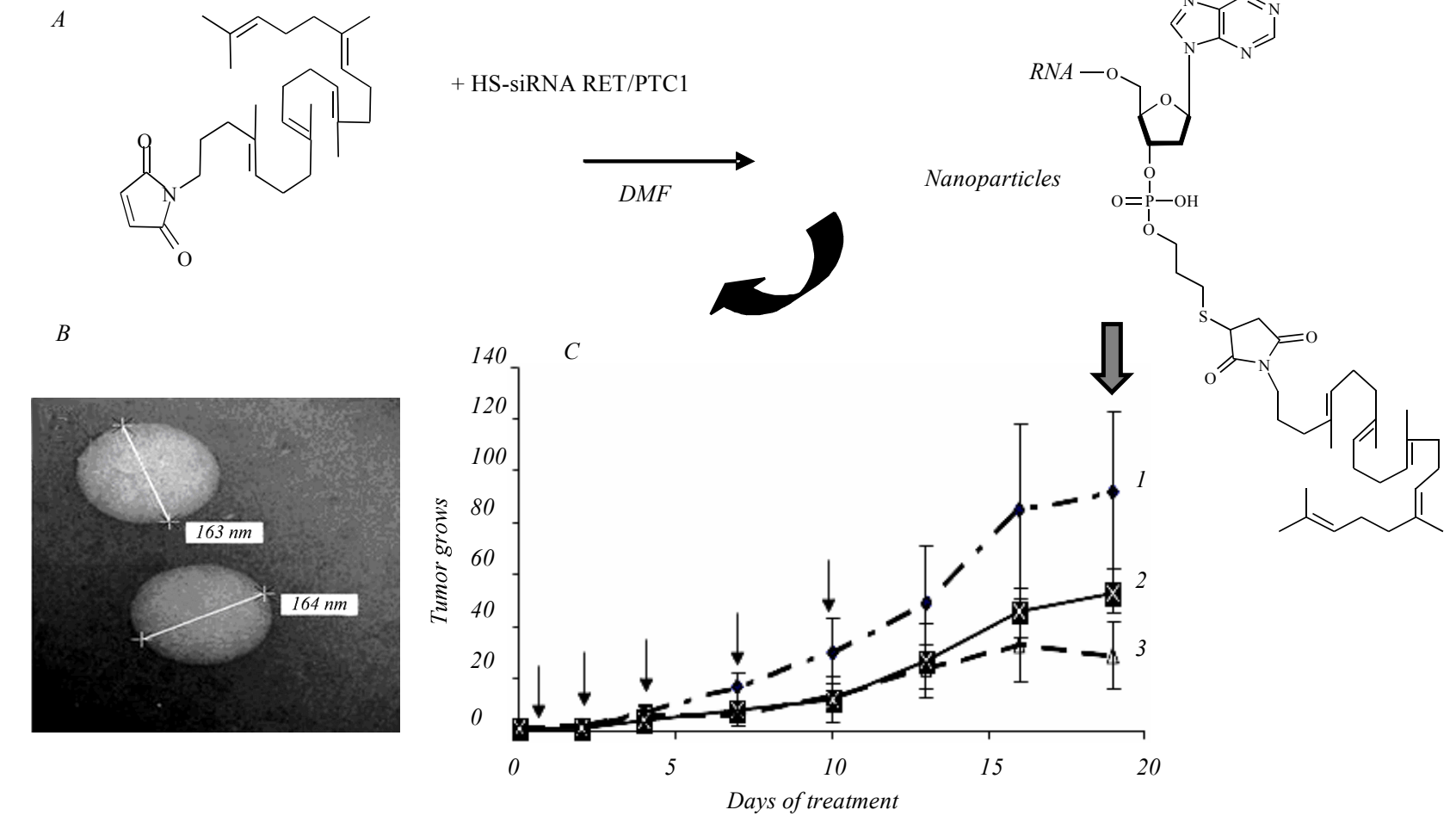

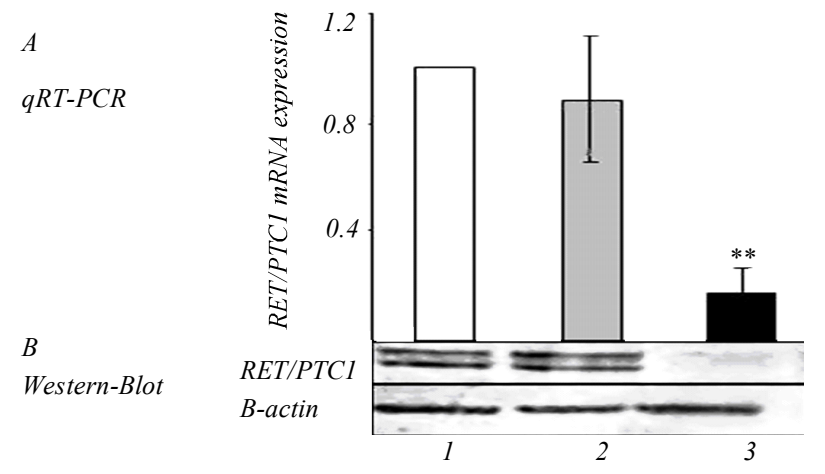

Fig. 1. Gene silencing efficiency of siRNA RET/PTC1 in TPC-1 cells: $A$ - the RET/PTC1 mRNA expression was analyzed by Q-RT-PCR for treated cells by siRNA RET/PTC1 (black) or siRNA CT (grey) and compared to untreated cells (white); the bars represent mean $\pm \mathrm{SD}$ of at least three independent experiments; $* * *$ significant change compared to untreated cells using ANOVA followed by Bonferroni's test ( $\mathrm{p}<$ $<0.001$ ); $B$ - RET/PTC-1 protein level in untransfected and transfected cells with siRNA RET/PTC1 or siRNA CT at $50 \mathrm{nM}$. Proteins were extracted $24 \mathrm{~h}$ after transfection and analyzed by Western blot using Ret antibody; $\beta$-actin was used as loading control for Western blot; experiments were performed in triplicate. 1 - untreated cells; 2 control siRNA; 3 - RET/PTC1 siRNA.

Fig. 2. $A$ - chemical structure of the siRNA sense strand 1 and of the squalenoyl activated moieties $2-5$ and conjugation of 1 with squalenoyl maleimide $5 ; B$ - characterization of siRNA-SQ RET/PTC1 NP. Representative images of the siRNA-SQ RET/PTC1 NPs obtained by cryo-electron microscopy, mean diameter $=164 \mathrm{~nm} ; C-$ antitumor effects of the siRNA-SQ RET/ PTC1 NPs. Curve $1-$ saline; $2-$ siRNA-CT-SQ NT; 3 siRET/PTC1-SQ NP. The treatment was performed by intravenous administration until day 10. Arrows correspond to the days of treatment. Five injections were performed for siRNA-SQ RET/ PTC1 or control] NPs at days $0,2,4,7$ and 10 at $2.5 \mathrm{mg} / \mathrm{kg}$ cumulative dose. $\Downarrow$ : Mice were sacrificed at day 19. The effects of siRNA-SQ RET/PTC1 NPs on tumour growth in nude mice are expressed relatively to tumour volume on day 1 according to the following formula: tumour volume at day $x$ /tumour volume at day 1 . Bars correspond to the standard deviation for five mice. A statistical difference was observed between treatments $(p=0.01)$ using the ANOVA test followed by Bonferroni test who showed a statistical difference between siRNA-SQ RET/PTC1 NP and untreated tumours (saline), $\mathrm{p}=0.013$ 
For vectorization, a non cationic new approach for the delivery of siRNA targeted toward the RET/PTC1 fusion oncogene; it is based on the concept of «squalenoylation», consisting in the bio-conjugation of a drug substance to squalene (SQ), a non ionic and biocompatible natural lipid $[17,18]$. The acyclic isoprenoid chain of squalene has been covalently coupled with siRNA RET/PTC1 at the 3'-terminus of the sense strand via maleimide-sulfhydryl chemistry. Nanoparticles were obtained by precipitation in $\mathrm{H}_{2} \mathrm{O}$. These nanoparticles were tested in vivo, on a mice xenografted RET/ PTC1 experimental model (Fig. 2).

Results and discussion. By Q-RT-PCR we found that both siRET/PTC1 significantly reduced the RET/ PTC1 mRNA levels by approximately $80 \%$. MTT assay showed a significant decrease in the TPC-1 growth rate in siRNA RET/PTC1-treated cells when compared to untreated cells. Cell cycle progression analysis showed a significant increase of the S-phase in siRNAstreated cells when compared with the untreated cells. Apoptotic cells were detected using TUNEL staining and a fluorescence microscope. Comprehensive counts showed a modest increase in apoptotic index of about $8.4 \pm 1.5 \%$ [19].

Then, we «squalenoylated» the siRNA RET/PTC1, remarkably, the linkage of siRNA RET/PTC1 to squalene led to amphiphilic molecule that self-organised in $\mathrm{H}_{2} \mathrm{O}$ as siRNA-SQ RET/PTC1 nanoparticles (NPs). In vivo, on a mice xenografted RET/PTC1, RET/PTC1SQ NPs were found to inhibit tumour growth and RET/ PTC1 oncogene and oncoprotein expression, after 2.5 $\mathrm{mg} / \mathrm{kg}$ cumulative dose intravenous injections [20].

Conclusions. The siRNA RET/PTC1 designed is efficient and specific to RET/PTC1 oncogene, which should open new prospects in treatments by siRNAs for PTC or Hurthle thyroid tumours with RET/PTC1 junction. The «squalenoylation» offers a new non cationic plate-form for the siRNA delivery. Further pharmacological assays are needed both on cell cultures and in vivo before to generalize this concept to other nucleic targets.

Acknowledgments. This paper summarizes a part of the PhD thesis work of Marie Gilbert-Sirieix (biological part) and of Mouna Raouane (chemical part). The chemical part of the study was done by the staff of Professor Patrick Couvreur and Doctor Didier Desmaele, UMR 8612 CNRS, laboratoire «Physico-chimie, pharmacotechnie \& Biopharmacie», faculte de Pharmacie, Chatenay-Malabry, France.

\section{Л. Массад}

Ефекти сайлесингу RET/PTC1 злитого онкогену у клітинах папілярної карциноми щитоподібної залози людини:

характеристика і векторизація міРНК, направлених на RET/PTC1

Резюме

Злитий онкоген RET/PTC1 є найзагальнішою генетичною зміною, ідентифікованою на сьогодні при папілярних ракових захворюваннях шитоооодібої залози (РТС); він являє собою гарну мішень для малих інтерферуючих РНК (міРНК). Мета роботи полягала у 1) діï на онкоген RET/PTC1 за посередництвом siPHK; 2) оцінюванні пошкоджуючого впливу на ріст клітин та і регуляцію клітинного цииклу; 3) векторизації для захисту від деградаџіï. Методи. Клітинні лінії людини, які експресують RET/PTC1 були трансфековані міРНК RET/PTC1, інгібування експресї даного онкогену аналізували qRT-PCR і вестерн блот. міPHK RET/PTC1 кон'югували зі скваленом. In vivo дослідження проводилися на безтимусних митах. Висновки. $У$ даному короткому повідомленні представлено основні опубліковані результати, отримані останніми роками.

Ключові слова: RET/PTC1, міРНК, папілярна карцинома щуитоподібної залози.

\section{Л. Массад}

Эффекты сайлесинга RET/PTC1 слитого онкогена в клетках папиллярной карциномы щитовидной железы человека: характеристика и векторизация миРНК, направленных на RET/PTC1 Резюме

Cлитый онкоген RET/PTC1 является самым общим генетическим изменением, идентифицированным на сегодня при папиллярных раковых заболеваниях щзитовидной железы (РТС); он представляет собой хорошую мишень для мальх интерферируюших РНК (миРНК). Цель работь состояла в 1) воздействии на онкоген RET/PTC1 посредством миРНК; 2) оценке повреждающего влияния на рост клеток и регуляцию клеточного цикла; 3) векторизациии для защиты от деградации. Методы. Клеточные линии человека экспрессирующие RET/PTC1 были трансфецированы миPHКRET/PTC1, ингибирование экспресии данного онкогена анализировалось qRT-PCR и вестерн блоттом. миPHК RET/ $P T C 1$ конъюгировали со скваленом. In vivo исследованя проводились на безтимусны мышах. Выводы. В данном коротком сообщении мы представляем основные опубликованные результаты, полученные в последние годы.

Ключевые слова: RET/PTC1, миРНК, папиллярная каричнома ичитовидной железы.

\section{REFERENCES}

1. Nambiar M., Kari V., Raghavan S. C. Chromosomal translocations in cancer // Biochim. Biophys. Acta.-2008.-1786, N 2.P. 139-152.

2. Teixeira M. R. Recurrent fusion oncogenes in carcinomas // Crit. Rev. Oncog.-2006.-12, N 3-4.-P. 257-271. 
3. Aman P. Fusion genes in solid tumors // Semin. Cancer Biol.1999.-9, N 4.-P. 303-318.

4. Jhiang S. M. The RET proto-oncogene in human cancers // Oncogene.-2000.-19, N 49.-P. 5590-5597.

5. Di Cristofaro J., Vasko V., Savchenko V., Cherenko S., Larin A., Ringel M. D., Saji M., Marcy M., Henry J. F., Carayon P., De Micco $C$. ret/PTC1 and ret/PTC3 in thyroid tumors from Chernobyl liquidators: comparison with sporadic tumors from Ukrainian and French patients // Endocr. Relat. Cancer.-2005.-12, N 1.-P. 173-183.

6. Nikiforov $Y$. E. Radiation-induced thyroid cancer: what we have learned from chernobyl // Endocr. Pathol.-2006.-17, N 4.P. 307-317

7. Fusco A., Grieco M., Santoro M., Berlingieri M. T., Pilotti S., Pierotti M. A., Della Porta G., Vecchio G. A new oncogene in human thyroid papillary carcinomas and their lymph-nodal metastases // Nature.-1987.-328, N 6126.-P. 170-172.

8. Fusco A., Santoro M. 20 years of RET/PTC in thyroid cancer: clinico-pathological correlations // Arq. Bras. Endocrinol. Metabol.-2007.-51, N 5.-P. 731-735.

9. Viglietto G., Chiappetta G., Martinez-Tello F. J., Fukunaga F. H., Tallini G., Rigopoulou D., Visconti R., Mastro A., Santoro $M$., Fusco A. RET/PTC oncogene activation is an early event in thyroid carcinogenesis // Oncogene.-1995.-11, N 6.P. 1207-1210.

10. Tallini G., Asa S. L. RET oncogene activation in papillary thyroid carcinoma // Adv. Anat. Pathol.-2001.-8, N 6.-P. 345-354.

11. Santoro M., Melillo R. M., Fusco A. RET/PTC activation in papillary thyroid carcinoma: European Journal of Endocrinology Prize Lecture // Eur. J. Endocrinol.-2006.-155, N 5.-P. 645653.

12. Nikiforova M. N., Stringer J. R., Blough R., Medvedovic M., Fagin J. A., Nikiforov $Y$. E. Proximity of chromosomal loci that participate in radiation-induced rearrangements in human cells // Science.-2000.-290, N 5489.-P. 138-141.

13. Nikiforov Y. E. RET/PTC rearrangement in thyroid tumors // Endocr. Pathol.-2002.-13, N 1.-P. 3-16.
14. Chiappetta G., Toti P., Cetta F., Giuliano A., Pentimalli F. Amendola I., Lazzi S., Monaco M., Mazzuchelli L., Tosi P., Santoro M., Fusco A. The RET/PTC oncogene is frequently activated in oncocytic thyroid tumors (Hurthle cell adenomas and carcinomas), but not in oncocytic hyperplastic lesions // J. Clin. Endocrinol. Metab.-2002.-87, N 1.-P. 364-369.

15. Brummelkamp T. R., Bernards R., Agami R. A system for stable expression of short interfering RNAs in mammalian cells // Science.-2002.-296, N 5567.-P. 550-553.

16. Bertling W. M., Gareis M., Paspaleeva V., Zimmer A., Kreuter $J$., Nurnberg E., Harrer P. Use of liposomes, viral capsids, and nanoparticles as DNA carriers // Biotechnol. Appl. Biochem.1991.-13, N 3.-P. 390-405.

17. Couvreur P., Reddy L. H., Mangenot S., Poupaert J. H., Desmaele D., Lepetre-Mouelhi S., Pili B., Bourgaux C., Amenitsch $H$., Ollivon $M$. Discovery of new hexagonal supramolecular nanostructures formed by squalenoylation of an anticancer nucleoside analogue // Small.-2008.-4, N 2.-P. 247-253.

18. Couvreur P., Stella B., Reddy L. H., Hillaireau H., Dubernet C., Desmaele D., Lepetre-Mouelhi S., Rocco F., DereuddreBosquet N., Clayette P., Rosilio V., Marsaud V., Renoir J. M., Cattel L. Squalenoyl nanomedicines as potential therapeutics // Nano Lett.-2006.-6, N 11.-P. 2544-2548.

19. Gilbert-Sirieix M., Ripoche H., Malvy C., Massaad-Massade L. Effects of silencing RET/PTC1 junction oncogene in human papillary thyroid carcinoma cells // Thyroid.-2010.-20, N 10.P. 1053-1065.

20. Raouane M., Desmaele D., Gilbert-Sirieix M., Gueutin C., Zouhiri F., Bourgaux C., Lepeltier E., Gref R., Ben Salah R., Clayman G., Massaad-Massade L., Couvreur P. Synthesis, characterization, and in vivo delivery of siRNA-squalene nanoparticles targeting fusion oncogene in papillary thyroid carcinoma // $\mathrm{J}$. Med. Chem.-2011.-54, N 12.-P. 4067-4076.

UDC 577.218

Received 20.06.11 